\title{
Spherocyte Count
}

National Cancer Institute

\section{Source}

National Cancer Institute. Spherocyte Count. NCI Thesaurus. Code C74707.

The determination of the number of spherocytes present in a sample. 